\title{
Hepatitis C pada Thalassemia mayor: pengaruh Iron Overload pada perjalanan penyakit
}

\author{
Ferry Damardjati, Hanifah Oswari
}

\begin{abstract}
Indonesia sebagai negara yang termasuk dalam thalassemia belt juga mengalami masalah dan komplikasi yang timbul akibat penyakit tersebut. Masalah klasik thalassemia adalah pemberian transfusi darah berulang yang mengakibatkan penularan penyakit melalui transfusi darah seperti hepatitis $\mathrm{C}$, di samping penimbunan besi di dalam berbagai organ dan jaringan. Penimbunan besi yang berlebihan (iron overload) akan mengakibatkan penurunan fungsi sistim imun pada pasien thalassemia yang juga akan berpengaruh pada perjalanan penyakit apabila terinfeksi oleh mikro organisme patogen. Pasien thalassemia yang terinfeksi virus hepatitis $\mathrm{C}$ (VHC) akan mengalami kerusakan hati baik akibat infeksi VHC maupun akibat terjadinya penimbunan besi karena mendapat tranfusi darah berulang tanpa pemberian kelasi besi yang adekuat. Pengobatan VHC pada thalassemia sampai saat ini belum ada yang adekuat sehingga uji tapis merupakan instrumen yang penting dalam mencegah penyakit tersebut.
\end{abstract}

Kata kunci: thalassemia, iron overload, hepatitis C, uji tapis.

$C$ ransfusi darah pada thalassemia merupakan pengobatan yang bertujuan untuk memperbaiki kondisi anemia agar tumbuh kembang anak dapat dipertahankan secara optimal. Komplikasi utama pengobatan thalassemia adalah terjadinya infeksi virus yang ditransmisikan melalui transfusi darah dan terjadinya penimbunan besi dalam jaringan. ${ }^{1-4}$ Penyakit hati pada thalassemia dapat diakibatkan oleh timbunan besi pada sel hati sebagai penyebab tunggal atau sebagai faktor yang memperberat kerusakan hati apabila terjadi bersamaan dengan infeksi virus hepatitis. ${ }^{5-7}$

Sejak Choo dkk. ${ }^{8}$ menemukan genom virus hepatitis C pada tahun 1989, semakin jelas bahwa sebagian besar kasus hepatitis non-A non-B pasca

Dr. Ferry Damardjati: PPDS Ilmu Kesehatan Anak FKUI, Jakarta

\footnotetext{
Alamat korespondensi:

Dr. Hanifah Oswari, Sp.A.

Staf Subbagian Hepatologi. Bagian Ilmu Kesehatan Anak FKUI-RSCM. Jl. Salemba no. 6. Jakarta 10430.

Telepon: 021- 3915712 dan Fax,: 021-390 7743.

e-mail: hanifah@idai.or.id.
}

transfusi ternyata disebabkan oleh virus hepatitis $\mathrm{C}$ (VHC). ${ }^{9}$ Penelitian di berbagai negara yang dilakukan untuk mendeteksi adanya infeksi VHC terhadap darah donor mendapatkan angka prevalens VHC 0,01-0,1\% di Inggris, Skandinavia, Eropa, dan Amerika Utara. Sedangkan prevalens VHC di Brazil, India, Afrika dan Asia berkisar antara 1-5\%. ${ }^{10}$ Sulaiman dkk. ${ }^{11}$ pada tahun 1992 melaporkan prevalens hepatitis C pada darah donor di 21 propinsi di Indonesia sebesar 2,1\%.

Tujuan tulisan ini untuk mendiskusikan pengaruh iron overload pada thalassemia yang menderita dengan infeksi VHC.

\section{Hepatitis C pada Thalassemia Mayor}

Lai dkk. ${ }^{12}$ melakukan penelitian prospektif selama 8 tahun pada 135 kasus thalassemia anak di Italia yang mendapat transfusi darah berulang. Dari penelitian tersebut didapatkan 83 anak $(61 \%)$ menderita hepatitis non-A non-B. Setelah dilakukan pemeriksaan terhadap antibodi VHC dengan menggunakan ELISA generasi kedua ternyata $90 \%$ kasus hepatitis non-A non-B menunjukkan anti-VHC positif. Di Surabaya, 
prevalens VHC pada thalassemia dilaporkan sebesar $21,4 \%$ di Surabaya. ${ }^{13}$ Penelitian yang dilakukan oleh Timan dkk. ${ }^{14}$ di Bagian Ilmu Kesehatan Anak RSUPN Dr. Cipto Mangunkusumo Jakarta, pada 153 kasus thalassemia yang diperiksa dengan menggunakan ELISA generasi pertama mendapatkan anti-VHC positif sebesar $31,37 \%$, negatif pada $41,2 \%$ dan meragukan pada $27,5 \%$. Pada kasus dengan anti-VHC yang meragukan dilakukan penelitian ulang dengan menggunakan ELISA generasi kedua dan ternyata didapatkan anti-VHC positif $67,7 \%$.

VHC merupakan virus dengan untaian tunggal RNA yang termasuk dalam famili flaviviridae; mempunyai selubung yang terdiri dari lemak dengan diameter 30-60 nm, panjang genom 9,5 kb terdiri dari 3000 asam amino dan 9400 nukleotida. ${ }^{15}$ Infeksi VHC pada thalassemia dapat terjadi melalui transmisi parenteral akibat transfusi darah yang berulang. Infeksi ini diperberat oleh adanya penimbunan besi pada sel hati serta keterkaitannya dengan penurunan fungsi imun. ${ }^{716-18}$ Uji Tapis yang dilakukan untuk mencegah terjadinya infeksi VHC terbukti efektif dalam menurunkan angka kejadian. Infeksi VHC masih dapat terjadi pada darah donor yang terbukti negatif, tetapi sebenarnya masih dalam window period infeksi VHC atau karena instrumen uji tapis yang kurang sensitif., ${ }^{6,19}$

\section{Patogenesis Infeksi VHC Kronik}

Kerusakan yang terjadi akibat infeksi VHC disebabkan oleh adanya respons imun yang saling berinteraksi dan kompleks. Respons imun yang terlibat pada infeksi VHC adalah respons imun non spesifik dan spesifik. Sistim imun non spesifik melibatkan sel natural killer. ${ }^{20}$ Sedang sistim imun spesifik dibedakan menjadi sistim imun humoral dan seluler. (Gambar 1)

Faktor virus memegang peranan utama dalam terjadinya kronisitas infeksi VHC kronik melalui mekanisme escape mutant sehingga dapat lolos dari sistim imun. ${ }^{9}$ Quasispecies merupakan variasi heterogenitas VHC pada seseorang yang terinfeksi VHC, sebagai akibat dari sifat VHC yang mudah mengadakan mutasi. Quasispecies tersebut merupakan mekanisme perlindungan VHC sehingga tidak dikenal oleh sistim imun atau limfosit $\mathrm{T}$ sitotoksik pejamu, yang berakibat infeksi VHC bersifat persisten. ${ }^{15,21}$ Honda dkk. ${ }^{22}$ melakukan studi terhadap genom quasispecies hepatitis $\mathrm{C}$ pada 28 kasus dengan gejala yang berbeda. Penelitian dilakukan dengan menganalisis sekuens genom VHC dari core sampai dengan envelope. Hasil penelitian menunjukkan bahwa keragaman quasispecies pada VHC berhubungan dengan progresivitas dan kronisitas penyakit.

Genotipe VHC menunjukkan heterogenitas genom VHC. Karakteristik VHC yang paling penting adalah adanya variasi sekuens nukleotida. ${ }^{21}$ Sampai saat ini telah ditemukan 6 genotipe VHC dengan pola penyebaran dan dominasi yang berbeda di setiap negara. Genotipe yang tersebar di seluruh dunia adalah tipe 1, 2, dan 3. Genotipe 4 banyak ditemukan di daerah Pan-Afrika, genotipe 5 banyak ditemukan di wilayah Afrika Selatan, dan genotipe 6 banyak ditemukan di wilayah Asia. ${ }^{23}$ Jenis genotipe yang terdapat di Indonesia adalah genotipe II/1b sebesar $43 \%$, III/2a sebesar $26 \%$ dan 1c sebesar $12 \% .{ }^{26}$ Sampai saat ini masih terus diteliti dan ditemukannya genotipe yang baru di wilayah yang berbeda. Perbedaan jenis genotipe ini akan mempengaruhi karakteristik perjalanan klinis dan respons terhadap pengobatan. Penelitian menunjukkan bahwa genotipe II/1b berhubungan dengan beratnya perjalanan penyakit serta terjadinya sirosis hati dan karsinoma hepatoseluler. ${ }^{24}$ Bruno dkk. ${ }^{25}$ melakukan studi prospektif pada 163 penderita sirosis hati dengan anti-VHC positif. Penelitian dilakukan untuk mengetahui timbulnya karsinoma hati dengan melakukan pemeriksaan ultrasonografi dan kadar alpha feto protein (AFP) setiap 6 bulan. Pada akhir penelitian ini didapatkan kasus dengan genotipe $1 \mathrm{~b}$ mempunyai risiko relatif sebesar 6 kali untuk menjadi karsinoma hepatoseluler dibandingkan dengan genotipe lain.

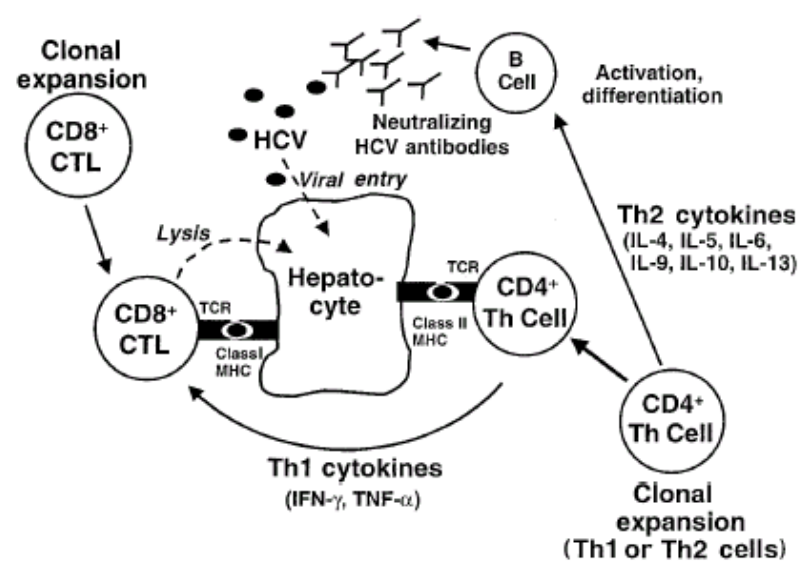

Gambar 1. Peran imunitas spesifik pada infeksi VHC ${ }^{20}$ 
Manifestasi infeksi VHC pada thalassemia menyerupai gambaran hepatitis $\mathrm{C}$ pada anak secara umum dan seringkali asimtomatis. Gejala hepatitis akan menjadi berat apabila terdapat ko-infeksi dengan virus hepatitis $\mathrm{B}$ atau HIV. ${ }^{27}$ Terjadinya gangguan fungsi hati dan VHC Kronik pada thalassemia bukan hanya disebabkan oleh infeksi VHC saja tetapi juga akibat penumpukan besi di hati. ${ }^{7}$ Pengaruh besi terhadap hepatitis virus kronis dapat dilihat pada Tabel 1.

Pada pasien thalassemia dengan iron overload akan terjadi penurunan fungsi serta populasi sel CD 8. Sel CD 8 berguna sebagai sel sitolitik untuk eradikasi infeksi VHC pada awal infeksi dengan menghasilkan interferon- $\gamma$. Menurunnya jumlah dan fungsi sel CD 8 akan mengakibatkan perjalanan penyakit menjadi kronik. ${ }^{16,28}$ Large $\mathrm{dkk} .{ }^{29}$ melaporkan adanya penekanan sistim imun seluler limfosit T sitotoksik yang diikuti dengan penekanan IFN- $\gamma$ dan IL 2 pada kasus VHC kronik oleh protein inti VHC.

Pergeseran keseimbangan sel Thelper (Th) ke arah Th 2 akan mengakibatkan pembentukan sistim imun humoral menjadi lebih dominan, sehingga infeksi VHC menjadi kronik. Weiss $\mathrm{dkk}^{18}$ melakukan penelitian pada 22 orang dengan penyakit hati akibat infeksi VHC, mendapatkan adanya pergeseran populasi ke arah sel Th 2 pada pasien dengan kadar transferin serum yang meningkat akibat penimbunan besi. Pergeseran ini berpengaruh pada timbulnya penyakit hati kronik. Pemberian transfusi darah berulang itu sendiri dapat mengakibatkan penularan beberapa jenis virus hepatitis sehingga akan terjadi immune exhaustion. ${ }^{7}$ Sifat virus yang mudah me-

Tabel 1. Mekanisme yang mungkin terjadi sebagai akibat penumpukan besi pada hepatitis virus kronik. ${ }^{7}$

Kemungkinan efek non spesifik

- Peningkatan stres oksidatif

- Peningkatan kerusakan lipid peroxidation

- Pengeluaran mediator inflamasi

Kemungkinan efek pada virus

- Peningkatan kecepatan replikasi virus

- Peningkatan kecepatan mutasi virus

Kemungkinan efek pada pejamu

- Penurunan fungsi imunitas selular

- Penurunan fungsi makrofag

- Penghambatan efisiensi klon Th 1 dan CTL

- Penurunan maturasi proliferasi sel T limfosit

- Penurunan fungsi imunitas humoral ngadakan mutasi juga ikut berperan dalam terjadinya infeksi VHC kronik. ${ }^{15,30}$

\section{Perjalanan penyakit hepatitis C}

Perjalanan infeksi VHC pada anak cenderung lebih ringan dibandingkan dewasa. Risiko menjadi penyakit hati kronik pada anak akibat infeksi VHC sebesar $50 \%-60 \% .{ }^{31}$ Perjalanan penyakit hepatitis $\mathrm{C}$ kronik yang didapatkan melalui transfusi masih belum sepenuhnya jelas. Tong. dkk ${ }^{32}$ melakukan penelitian retrospektif pada 131 kasus dewasa dengan riwayat transfusi berulang yang diikuti selama 4 tahun. Selama pengamatan, 20 orang meninggal terbagi atas 8 kasus sirosis hati, 11 karsinoma hepatoseluler, dan 1 karena komplikasi lain. Hepatitis $C$ kronik pasca transfusi merupakan penyakit progresif yang dapat mengakibatkan kematian. Sebaliknya Harris dkk. ${ }^{33}$ yang melakukan penelitian retrospektif pada 449 kasus dengan VHC kronik pasca transfusi yang diamati selama 10 tahun mendapatkan hasil bahwa infeksi VHC secara tunggal tidak berperan besar dalam morbiditas dan mortalitas.

Risiko kematian akan meningkat pada pengguna alkohol yang berlebihan. Vogt $\mathrm{dkk}^{34}$ melakukan pengamatan selama 20 tahun pada 458 anak yang menjalani prosedur pembedahan jantung yang mendapatkan transfusi darah. Hasil yang didapat pada saat awal pemeriksaan dengan menggunakan ELISA generasi kedua didapatkan 67 dari 458 kasus mempunyai anti-VHC positif. Setelah pengamatan 20 tahun pada 67 kasus tersebut, hanya 37 kasus diantaranya mempunyai anti-VHC positif, dan 30 lainnya mempunyai anti-VHC dan RNA VHC negatif. Perjalanan klinis hepatitis $\mathrm{C}$ pada anak jauh lebih ringan dibandingkan dengan orang dewasa, tetapi Resti dkk. ${ }^{35}$ melaporkan 78 kasus thalassemia anak dengan riwayat transfusi berulang yang diamati selama 13 tahun, terjadi sirosis hati pada 30\% kasus.

Gambaran klinis pada anak dengan hepatitis C umumnya asimtomatik. Timan IS, ${ }^{14}$ melaporkan gambaran klinis hepatitis $\mathrm{C}$ pada kasus thalassemia anak yang menunjukkan ke arah hepatitis seperti mual, muntah, dan urin berwarna gelap ditemukan pada 6 dari 19 kasus. Keluhan lain seperti kuning, kelemahan umum, dan menggigil merupakan keluhan yang sering dijumpai pada kasus thalassemia. ${ }^{14}$ 


\section{Pencegahan}

Sifat VHC yang cenderung menjadi kronik dan progresif serta persentasi keberhasilan terapi yang belum memuaskan menempatkan tindakan pencegahan pada posisi strategis. Variasi genotip dan mutasi VHC yang tinggi menyebabkan pembuatan vaksin terhadap VHC masih menemui kesulitan. ${ }^{12}$ Tindakan pencegahan melalui uji tapis VHC terhadap darah donor merupakan salah satu cara pencegahan yang dapat dilakukan. Uji tapis VHC pada darah donor dapat menurunkan sekitar setengah kasus hepatitis pasca transfusi. ${ }^{3}$ Beberapa cara untuk mencegah hepatitis pada thalassemia melalui transfusi darah antara lain dengan seleksi donor melalui uji tapis VHC terhadap darah donor, inaktivasi virus yang ada pada faktor pembekuan melalui pemanasan, solvent detergent, antibody monoclonal, pemanasan kering pada suhu $80^{\circ} \mathrm{C}$ selama $72 \mathrm{jam}$, fotokimiawi dengan cara menginaktivasi asam nukleat seperti DNA dan RNA virus tanpa merusak sel darah merah. ${ }^{3,14}$

Dari berbagai cara tersebut di atas, seleksi donor darah dengan menggunakan uji tapis merupakan cara yang paling efektif karena di samping murah juga dapat menurunkan infeksi VHC pasca transfusi sebanyak $60 \% .{ }^{19}$

Banyak penelitian menunjukkan bahwa pemberian kelasi besi dapat memperbaiki fungsi sistim imun dan fungsi organ yang menurun akibat penimbunan besi. ${ }^{16-}$ 18,30,36 Jenis obat yang digunakan untuk terapi kelasi besi adalah deferoxamine dan deferiprone. ${ }^{37,38}$ Saat ini obat kelasi besi yang banyak digunakan adalah jenis deferoxamine karena efektifitas dan keamanannya telah terbukti dengan baik. Di Bagian Ilmu Kesehatan Anak FKUI/RSCM adalah dengan menggunakan deferoxamine yang diberikan secara subkutan dengan menggunakan syringe pump. ${ }^{38}$ Penggunaan deferiprone secara oral tidak dianjurkan karena efektifitas yang kurang baik dibandingkan dengan deferoxamine. Olivieri dkk. ${ }^{39}$ melakukan penelitian prospektif selama 7 tahun pada 19 kasus thalassemia dengan transfusi darah berulang yang mendapatkan deferiprone oral dibandingkan dengan 20 kasus yang mendapatkan deferoxamine. Penilaian dilakukan dengan melakukan pengukuran kadar besi dan progresivitas fibrosis dari biopsi hati. Dari penelitian tersebut didapatkan 5 kasus kelompok deferiprone mengalami progresivitas fibrosis hati, sedangkan pada kelompok deferoxamine tidak didapatkan. Penelitian ini menggambarkan bahwa penggunaan deferiprone secara oral tidak adekuat dalam mengurangi penimbunan besi pada penderita thalassemia sehingga tidak dapat mencegah progresivitas fibrosis hati.

\section{Daftar Pustaka}

1. Higgs DR, Thein SL, Wood WG. /The biology of the thalassaemia. Dalam: Weatherall DJ, Clegg JB, penyunting. The thalassaemia syndromes. Edisi keempat. Edinburgh: Blackwell Science, 2001. h. 65-237.

2. Olivieri NE. The $\beta$-thalassemias. N Engl J Med 1999; 341:99-109.

3. Tobler LH, Busch MP. History of posttransfusion hepatitis. Clin Chem 1997; 43:1487-93.

4. Schreiber GB, Busch MP, Kleinman SH, Korelitz JJ. The risk of transfusion-transmitted viral infection. $\mathrm{N}$ Engl J Med 1996; 334:1685-90.

5. Li CK, Chik KW, Lam CWK, To KF, Yu SCH, Lee V. Liver disease in transfusion dependent thalassaemia major. Arch Dis Child 2002; 86:344-7.

6. Prati D, Zanella A, Farma E, De Mattei C, Bosoni P, Zappa M. A multicenter prospective study on the risk of acquiring liver disease in anti-hepatitis $C$ virus negative patients affected from homozygous $\beta$-thalassemia. Blood 1998; 92:3460-4.

7. Bronkovsky HL, Banner BF, Rothman AL. Iron and chronic viral hepatitis. Hepatology 1997; 25:759-68.

8. Choo QL, Kuo G, Weiner AJ, Overby LR, Bradley DW, Houghton $M$. Isolation of a cDNA clone derived from blood-borne non-A, non-B viral hepatitis genome. Science 1989; 244:359-62.

9. Kuo G, Choo QL, Alter HJ, Gitnick GL, Redeker AG, Purcell RH, dkk. An assay for circulating antibodies to a major etiologic virus of human non-A, non-B hepatitis. Science 1989; 244:362-4.

10. Wasley A, Alter MJ. Epidemiology of hepatitis C: geographic differences and temporal trends. Semin Liver Dis 2000; 20:1-16.

11. Sulaiman A, Julitasari, Sie A, Rustam M, Melani W, Corwin A, dkk. Prevalence of hepatitis B and C in healthy Indonesian blood donors. Trans R Soc Trop Med Hyg 1995; 89:167-70.

12. Lai ME, De Virgilis S, Argiolu F, Farci P, Mazzoleni AP, Lisci V, dkk. Evaluation of antibodies to hepatitis C virus in a long-term prospective study of posttransfusion hepatitis among thalassemic children: comparison between first-and second-generation assay. J Pediatr gastroenterol Nutr 1993; 16:458-64.

13. Arief S. Hepatitis C virus. Dalam: Soetjiningsih, Sukardi R, Subanada IB, Sanjajayaputra IGN, Mahalini DS, penyunting. Proceedings of $12^{\text {th }}$ the national congress of child health; 2002 Jun 30-Jul 4; Bali, Indonesia. Bali; Dept of child health University Udayana; 2002. h. 409-18.

14. Wiharta AS, Timan IS. Hepatitis C pada penderita talasemi. Dalam: Wiharta AS, Zulkarnain Z, Purnamawati SP, penyunting. Naskah lengkap PKB IKA XXVII. Hepatologi anak masa kini; 1992 Nov 
6-7; Jakarta. Jakarta: Balai Penerbit FKUI; 1992. h. 163-169.

15. Lauer GM, Walker BD. Hepatitis $\mathrm{C}$ virus infection. $\mathrm{N}$ Engl J Med 2001; 345:41-52.

16. Rundles SC, Giardina PJ, Grady RW, Califano C, McKenzie P, de Sousa M. Effect of transfusional iron overload on immune response. J Infect Dis 2000; 182suppl:115S-21S.

17. Akbar AN, Bocarsly AF, de Sousa M, Gardina PJ, Hilgartner MW, Grady RW. Decreased natural killer activity in thalassemia major: a possible consequence of iron overload. J Immunol 1986; 136:1635-1640.

18. Weiss G, Umlauft F, Urbanek M, Herold M, Lovevsky M, Offner F, dkk. Association between cellular immune effector function, iron metabolism, and disease activity in patients with chronic hepatitis c virus infection. J Infect Dis 1999; 180:1452-1458.

19. Esteban JI, Gonzales A, Hernandez JM, Viladomiu L, Sanchez C, Talavera JL, dkk. Evaluation of antibodies to hepatitis $\mathrm{C}$ virus in a study of transfusionassociated hepatitis. N Engl J Med 1990; 323:11071112.

20. Liang TJ, Reherman B, Seef LB, Hoofnagle JH. Pathogenesis, natural history, treatment and prevention of hepatitis C. Ann Intern Med 2000; 132:296-305.

21. Farci P, Purcell RH. Clinical significance of hepatitis C virus genotype and quasispecies. Semin Liv Dis 2000; 20:103-122.

22. Honda M, Kaneko S, Sakai A, Unoura M, Murakami S, Kobayashi K. Degree of diversity of hepatitis C virus quasispecies and progression of liver disease. Hepatology 1994; 20:1144-1151.

23. Purcell R. The hepatitis C virus: overview. Hepatology 1997;3. suppl1:11S-4S.

24. Forns X, Bukh J. The molecular biology of hepatitis C virus. Genotypes and quasispecies. Clin Liver Dis 1999; 3:693-716.

25. Bruno S, Silvi E, Crosignani A, Borzio F, Leandro G, Bono $\mathrm{F}$, dkk. Hepatitis $\mathrm{C}$ virus genotypes and risk of hepatocellular carcinoma: a prospective study. Hepatology 1997; 25:754-758.

26. Lesmana LA, Sulaiman A, Noer MS, Tsuda F, Okamoto H. Hepatitis C virusgenotypes and co-infection with GB virus $\mathrm{C}$ in patients with anti-HCV-positive chronic Liver disease in Jakarta, Indonesia. International Hepatologi Communication 1996; 6:16-23.
27. Schwimmer JB, Balistreri WF. Transmission, natural history, and treatment of hepatitis $C$ virus infection in the pediatric population. Semin Liv Dis 2000; 20:37-46.

28. Gruner NH, Gerlach TJ, Jung MJ, Diepolder HM, Schirre CA, Schraut WW. Association of hepatitis C virus specific $\mathrm{CD} 8 \mathrm{~T}$ cells with viral clearance in acute hepatitis C.J Infect Dis 2000; 181:1528-36.

29. Large MK, Kittlesen DJ, Hahn YS. Suppresion of host immune response by the core of protein hepatitis $\mathrm{C}$ virus: possible implication for hepatitis $\mathrm{C}$ virus persistence. J immunol 1999; 162:931-8.

30. Bronkovsky HL, Lambrecht RW. Patophysiology of liver disease. Iron-induced liver injury. Clin Liver Dis 2000; 4:409-29.

31. Hoofnagle JH. Course and outcome of hepatitis C. Hepatology 2002; 36:21S-29S.

32. Tong MJ, El Farra NS, Reiks A. Clinical outcomes after transfusion associated hepatitis C. N Engl J Med. 1995; 332:1463-66.

33. Harris HE, Ramsay ME, Andrews N. Clinical course of hepatitis $\mathrm{C}$ virus during the first decade of infection: cohort study. Br Med J 2002; 324:3-8.

34. Vogt M, Lang T, Frosner G, Klinger C, Sendl AF, Zeller A, dkk. Prevalence and clinical outcome of hepatitis C infection in children who underwent cardiac surgery before the implementation of blood-donor screening. $\mathrm{N}$ Engl J Med 1999; 341:886-70.

35. Resti M, Azzari C, Rossi ME, Vullo C, Zammarchi E, Vierucci A. Hepatitis $C$ virus antibodies in a long-term follow-up of beta-thalassaemic children with acute and chronic non-A non-B hepatitis. Eur J Pediatr 1992; 151:5736. [Abstrak].

36. Andrews NC. Disorders of iron metabolism. N Engl J Med 1999; 341:1986-95.

37. Kushner JP, Porter JP, Olivieri NF. Secondary iron overload. Haematology 2001:47-61. didapat dari http:// www.asheducationbook.org/cgi/content/full/2001/1/47. diakses 25-2-2003.

38. Sub-Bagian Hematologi. Petunjuk diagnosis dan tatalaksana kasus thalassemia. Jakarta: Bagian Ilmu Kesehatan Anak FKUI/RSCM; 1997.

39. Olivieri NF, Brittenham GM, McLaren C, templeton DM, Cameron RG, Mcleland RA, dkk. Long-term safety and effectiveness of iron-chelation therapy with deferiprone for thalassemia major. N Engl J Med 1998; 339:417-23. 